\title{
An Investigation into the Relatively Low Uptake of Residential Stock within South African Real Estate Investment Trusts
}

\author{
Saul Nurick ${ }^{1}$, Luke Boyle ${ }^{2}$, Oliver Allen ${ }^{3}$, Greg Morris ${ }^{4}$, and Jacques Potgieter ${ }^{5}$ \\ ${ }^{1-5}$ Urban Real Estate Research Unit, Department of Construction Economics and Management, University \\ of Cape Town, South Africa
}

To cite this article: Nurick, S.D., Boyle, L., Allen, O., Morris, G., \& Potgieter, J. (2018). An Investigation into the Relatively Low Uptake of Residential Stock within South African Real Estate Investment Trusts. Journal of African Real Estate Research, 3(1), pp.61-80. DOI: 10.15641/jarer.v1i1.491.

\begin{abstract}
Since the establishment of the first South African Real Estate Investment Trust (REIT) in 2013, the listed property sector has seen significant growth with a current market capitalisation of R400 billion in comparison to 1998 where the market capitalisation was R5 billion. However, South African REITs invest less in the residential sector when compared to the global REIT market. The purpose of this research was to determine the factors that have attributed to this low uptake of residential stock. This was achieved using a qualitative survey consisting of semi-structured interviews with listed property fund managers and upper management from four REITs listed on the South African stock exchange. The findings indicated a number of factors that have influenced the low uptake of residential stock. These have been identified as the financial performance of residential real estate in South Africa, the nature of residential real estate, and the maturity of the REITs sector in South Africa. These findings make a valuable contribution to the very limited literature on REITs in South Africa. Furthermore, understanding these factors is crucial in further developing the REITs sector in South Africa which has the potential to catalyse broader developments for housing and the economy.
\end{abstract}

Keywords: Real Estate Investment Trusts (REITs); Residential Property; Listed Property; South Africa

\section{Introduction}

Since the formal introduction of REITs in 2013, the South African listed property sector has consistently performed well in terms of international standards (Anderson \& Cloete, 2016). South Africa's listed property market has traditionally invested in the office, retail and industrial sectors. Unlike many developed and developing property markets, there has been very little 
investment in the residential property sector by the South African listed property sector (Anderson \& Cloete, 2016). This is possibly due to certain barriers that are unique to the South African residential sector which are not experienced by the other three traditional property sectors. Furthermore, the South African REIT market is relatively young, and therefore relatively little research has been conducted in this area in comparison to more mature REIT markets. International REITs have a larger proportion of residential stock (14\%) in their portfolios compared to that of South Africa (3\%) (Indluplace, 2017a; NAREIT, 2017a). This is a significant difference. Residential property requires equal attention to that of the other main property sectors. This is due to the residential sector playing a role in underpinning the performance of office, retail and industrial property. For example, the location of residential nodes can potentially create demand for other property types, and vice versa. While it is clear that REITs tend to focus more on commercial real estate, their role in the residential sector is essential and provides a significant amount of housing and residential stock. Nevertheless, the significance and performance of residential REITs have received limited attention particularly in emerging markets (Newell \& Fischer, 2009). Evidence suggests that residential property can play a substantial role in less developed markets (Anderson \& Cloete, 2016). Furthermore, residential property in other emerging market REITs typically makes up $15 \%$ of the total stock (Broll, 2014). This is comparable with more developed REITs markets of the Global North where residential stock comprises $14 \%$ of the REITs sector.

South Africa is currently in the grips of a severe housing crises and the estimated deficit for formal housing is between 2-3 million (CAHF, 2017a). Considering this housing shortage, coupled with the challenges that national and local government face in addressing this vast backlog, there is a need to leverage private sector resources to address issues of housing provision and affordability. It is argued that it is vital to understand the factors that have attributed to REITs' relatively low level of investment in South Africa's residential real estate. Thus, the rationale behind this research is driven by the belief that defining the factors which limit the investment of REITs in residential real estate can help build an understanding of what is needed to grow this dimension of REITs. On a broader level, this rationale and subsequent research aims to help address the significant housing shortage that exists in most South African cities. Presently, there is very little academic literature on residential REITs in South Africa, this also includes the listed sector as a whole.

Findings were based on series of survey interviews with experts in the REIT sector in South Africa. The interviews provided key insights into the challenges relating to residential property investment in South Africa. Participants were questioned on their opinions and experiences with regards to the financial performance of residential property, the nature of residential property with a specific focus on management and lease structure, status/maturity of the South African REIT sector, and the affordable housing rental market. 
The findings highlight key aspects of the South African REIT sector that attribute to the low uptake of residential stock in REITs' portfolios. The qualitative data retrieved from the interviews was organised thematically into the following key themes: the nature of residential real estate in South Africa; the financial performance of residential real estate in South Africa; and the maturity of South African REIT sector. Understanding these areas of concern is likely to play a significant role in unlocking the potential of the REITs sector, increasing local and international investment, while also helping to address some of the challenges relating to housing South Africa.

The structure of the paper provides a brief discussion on the history of REITs both from a global and South African perspective. Thereafter, further discussion is provided on the South African residential property sector. An explanation of the methodology follows this before the presentation of the findings. The subsequent discussion section provides insight into the findings. The paper concludes with a summary including recommendations for future research.

\section{Background to the Study}

\subsection{Real Estate Investment Trusts (REITs)}

The standard REIT model was established in the USA in 1960 through the Real Estate Investment Trust Act and has since become a standard model for REITs around the world (Brounen \& de Koning, 2013). The model has been adopted in more than 35 countries (NAREIT, 2017c).

A REIT can be defined as a company that owns or finances income-producing real estate (Arizona State University, 2017; NAREIT, 2017a). REITs provide investors with regular income streams, diversification of a portfolio and longterm capital appreciation (NAREIT, 2017c). The REITs structure was established to allow individuals to participate in the remunerations available to large institutional investors that own or finance commercial real estate (Packer et al., 2014). The main benefit that a REIT offers is that it allows investors to trade stocks rather than a physical asset. This creates greater exposure to immovable property without having to invest relatively large amounts of money (JSE-Limited, 2010). REITs also allows private investors to diversify across multiple property sectors at a fraction of the cost, which in turn minimises risk (SA REIT, 2014; SA REIT, 2018). REITs are also exempt from corporate tax provided they distribute all taxable income to shareholders (NAREIT, 2017c). The shareholders, however, will pay income taxes at their marginal rate on the dividends received unless they are held in a tax-deferred account (NAREIT, 2017c).

To qualify as a REIT in the USA (country of origin), a company must meet the dividend distribution requirement of paying a minimum of $90 \%$ of its taxable income in the form of dividends to shareholders each year. The operational requirements state that a REIT must invest at least $75 \%$ of its total assets in real estate. Furthermore, a REIT must derive at least $75 \%$ of its gross income from rental income of real property, interest on mortgages financing 
real property and from the sale of real estate. However, these requirements differ depending on the country (Block, 2012).

As of July 2016, NAREIT global real estate index reported that the global REITs sector comprised of 482 listed property fund companies on various stock exchanges across 38 different countries (NAREIT, 2017c). These companies make up a consolidated market capitalisation of $\$ 1.6$ trillion (NAREIT, 2017b). On a global scale, REITs rank sixth in market capitalisation out of all the listed industries.

\subsection{South African REITs Sector}

REITs in South Africa are defined as a company that owns and operates income-producing immovable property (JSE-Limited, 2010; Cliffe Dekker Hofmeyr, 2017). REIT stocks are traded publicly on the JSE (SA REIT, 2017). REITs on the JSE have a diverse investment portfolio that has a range of assets such as shopping centres, office buildings, hospitals, hotels, residential properties and a range of others, with a minority having a specialised portfolio in only one sector (SA REIT, 2014). Prior to the establishment of REITs in 2013, the only two forms of publicly traded property investment entities were property loan stocks (PLS) and property unit trusts (PUT) (Ntuli \& Akinsomi, 2017; Ramjee, 2017).

The introduction of Section 25BB of the South African Income Tax Act in 2012 saw the introduction of legislation that enabled companies to list as REITs. The conversion to the REIT structure aimed to ensure consistency with foreign listed property markets in order to attract cross-border transactions between local and international investors. As a result, South African REITs can invest offshore (Ntuli \& Akinsomi, 2017; SA REIT, 2017). This has allowed local investors exposure to mature property investment markets while benefiting from a currency hedge and favourable investment parameters, such as low interest rates compared to initial yields (SA REIT, 2017). Recent data has shown that $40 \%$ of earnings from South African REITs are being generated from offshore portfolios (SA REIT, 2017). South African REITs also enjoy similar tax dispensations to that of other international REIT markets, where individual shareholders are taxed at their marginal rate with regards to REIT distributions (Miller, 2014; Ntuli \& Akinsomi, 2017).

The South African the listed property market at the time of this study comprised four types of property entities listed on the Johannesburg Stock Exchange (JSE). These were; PUT, Property Holding and Development Companies, REITs and PLS (JSE-Limited, 2010). Over the past decade, the South African listed property sector has seen significant growth (De Klerk, 2013). The South African REITs market is the 9th largest market of its type globally (Ntuli \& Akinsomi, 2017).

As of 2017, there were 36 REIT members listed on the JSE (www.reits.co.za, 2017). There is currently one South African REIT that solely focuses on residential property. Over three quarters $(78 \%)$ of properties owned by South African REITs comprise of retail and office sectors, with the remainder 
including industrial, hotel and residential (3\%), as shown in Figure 1. Figure 2 shows that the residential rental sector comprises only a sixth (17\%) of the total South African property market.

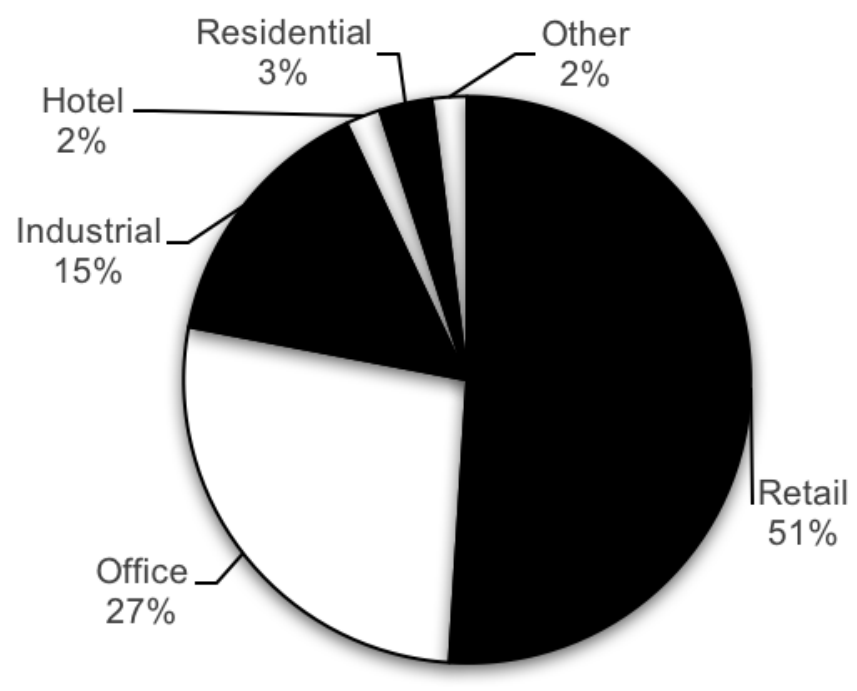

Figure 1: South African REIT Sectorial Segmentation (Growthpoint, 2016:6)

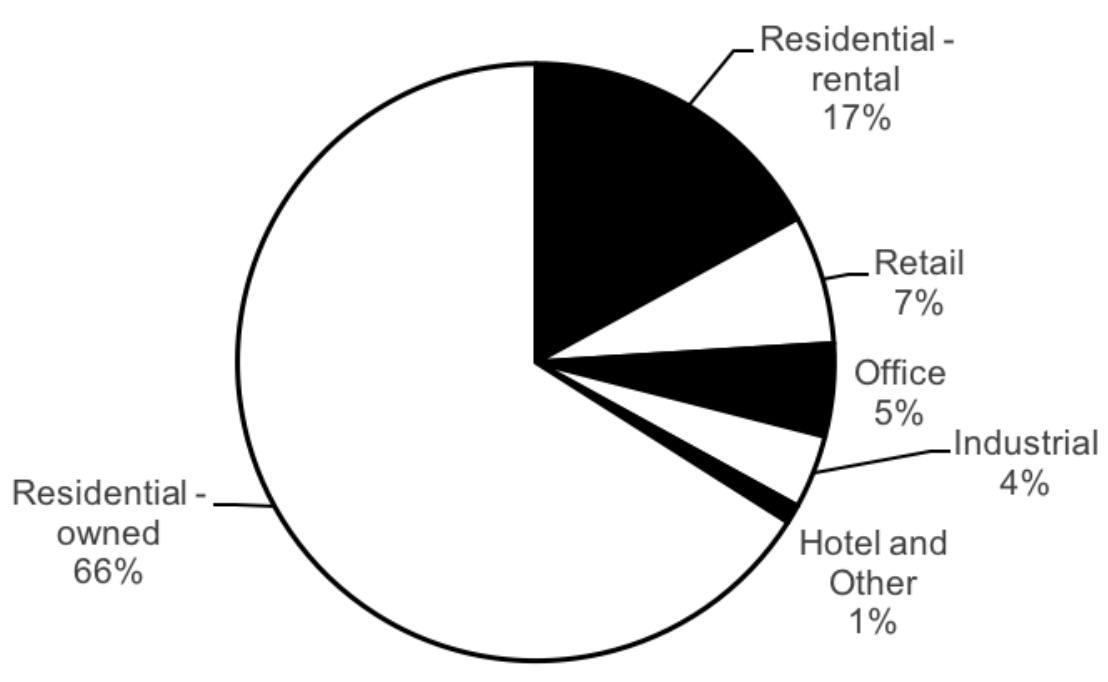

Figure 2: South African Property Market Sectorial Segmentation (Coronation, 2017:21)

The attractiveness of the REIT structure has resulted in some South African REITs considering the South African residential property sector as a potential investment opportunity, as the majority (83\%) of South African property is classified as residential. There have been recent opportunities for residential investment by South African REITs, which are underpinned by increasing urbanisation - its resultant growth in the rental market and increased rental prices. Additionally, an increase in the demand for residential rental space has 
been due to a reduction in available finance for residential acquisitions (CAHF, 2017b). The result of this, is an increase in demand for rental accommodation which both public and private sector are yet to respond to adequately. Consequently, the residential sector needs to be unpacked further in order to identify drivers and barriers as it only comprises $3 \%$ of South African REITs.

\section{The South African Residential Property Sector}

South Africa has experienced tough economic conditions and socio-political challenges that have affected the residential property market (Golding, 2016). Nationally there has been a slow decline of GDP growth from 5.6\% in 2006 to $1.3 \%$ in 2016 (World Bank, 2017). South Africa's residential property market is the largest sector of the South African property market (CAHF, 2015). In 2013, the deeds registry accounted for 6.7 million registered properties, and of these, approximately $86 \%$ are considered residential accommodation. This includes estates, government-sponsored housing, sectional title and freehold properties (CAHF, 2017a).

The residential property market can be split into four segments. These are values under R300,000 (44\%), R300,000 - R600,000 (19\%), R600,000 $\mathrm{R} 1,200,000$ (22\%) over R1,200,000 (15\%) of the residential property market (CAHF, 2017b). The most rapid growth in these sectors is in the R300,000 or under range due to the impact of governments subsidised housing programmes in South Africa (CAHF, 2017b). Low-cost housing is viewed by some as an untapped market due to a housing shortage in South Africa as a result of the legacy of Apartheid. Government housing programs have not managed to adequately address the demand for housing, thus its potential opportunity for the private sector. Rapid urbanisation has created an everincreasing housing backlog which has led to a demand for residential housing that far outstrips current attempts to supply housing, by both the public sector and private sector. Anderson and Cloete (2016) also highlight the massive room for growth that the affordable housing sector offers investors.

On average the South African residential housing price grew by $5.5 \%$ in 2015 to $5.7 \%$ in 2016 (Golding, 2016), due to the rand weakening and escalating food prices. The Consumer Price Index (CPI) has averaged $6.2 \%$ during this period (Bloomberg, 2016). This suggests that real housing prices have fallen by $0.5 \%$ from 2015 (Golding, 2016). This data can be misleading as certain urban nodes, suburbs and types of property have excelled despite the external challenges facing the residential market (Golding, 2016). For example, the Western Cape has seen housing prices increase by $10.3 \%, 4 \%$ in real terms (Golding, 2016). The high demand in the Western Cape has been caused by growing foreign investment and an influx of buyers relocating from other parts of the country (Smith, 2016). As stated above, the growing demand for residential real estate has resulted in the increase in housing prices in Cape Town. The Northern Coast of Kwa-Zulu Natal has seen similar trends to the Western Cape (Golding, 2016). The Kwa-Zulu Natal commercial sector is expanding at a rapid rate, with an emphasis being placed on office space (Seftleben, 2016). This has caused a growing demand for residential space in 
the area, and many apartment blocks have been developed to cater to working professionals (Seftleben, 2016). This case supports the modern notion of professionals wanting to work close to where they live (Hamm, 2013). Residential flats in Umhlanga have had a nominal increase of $31 \%$ growth since 2013, averaging at $10 \%$ growth per year for the last three years (Property24, 2017). Note that the above discussion relates primarily to urban residential real estate.

The residential market has seen a shift from freehold homes towards sectional title schemes and gated communities (Golding, 2016). In Johannesburg, the number of freestanding homes purchased has decreased by $25 \%$ since 2013 , and the number of flats purchased has increased by 5\% (Property 24,2017 ). Major gated communities such as Steyn City in Gauteng have been developed in South Africa. Both gated communities and sectional title schemes promote safe living conditions which are a main concern when purchasing residential accommodation (Golding, 2016). The aforementioned residential property types are seen to be attractive investments for REITs such as Indluplace and Redefine Properties, given that they feature residential property in their portfolios.

The above highlights that there is indeed a great deal of potential for investors within the residential sector in urban South Africa. This sentiment is beginning to be recognised by REITs. To exploit this opportunity a greater understanding of the conditions that facilitate the introduction of residential REITs is required (Anderson \& Cloete, 2016). To this end, it is suggested that defining the factors that have resulted in the low investment in residential stock will enable a deeper understanding of what needs to be done to exploit the opportunities that exist in the residential property sector in South Africa.

\section{Research Method}

The overarching research methodology for this study was a qualitative survey. Through a set of semi-structured interviews, resultant qualitative data was captured and analysed. A qualitative research methodology is used to investigate and attain a greater understanding of phenomenon within real-life settings (Patton, 1990; Yin, 2006). Therefore, in order to conduct thorough qualitative surveys, a unit of analysis must be defined. This unit of analysis should be pitched in the form of a research question (Dul \& Hak, 2007; Yin, 2013), which for this research is: Why is there relatively low uptake of residential stock within South African REITs? Therefore, the unit of analysis is South African REITs.

Both purposive and convenience sampling were implemented in order to acquire the required data. The main sample comprised of four South African REITs in addition to an organisation that invests in REITs on the JSE on behalf of other investors. The latter was chosen as a participant organisation as it provides a holistic view of the REITs sector without indicating any bias towards any particular REIT or portfolio strategy. 
In terms of the REITs that participated in this research, three invested in a combination of office, retail and industrial property, with no exposure to residential stock. These three were chosen as they represent the current investment sentiment of South African REITs (to invest in diversified portfolios). The remaining REIT specialised exclusively in residential real estate, the only one of its kind in South Africa. This REIT was chosen to participate in this study as it represented a contrasting investment strategy and will likely add valuable insights into the challenges and opportunities of investing in residential real estate on the listed sector.

With the research question and sampling methodology in mind, the approach therefore centred on semi-structured interviews with property professionals working in the South African listed property sector. Interview participants were asked a range of questions which were defined by the initial review of literature that was conducted prior to data collection. These questions inquired about participant's perceptions around residential real estate investment, the general state of the South African REITs sector, and the residential market in South Africa as a whole.

Table 1: A Breakdown of the Respondents and their Roles within their Organisations.

\begin{tabular}{|c|l|c|}
\hline $\begin{array}{c}\text { Participant } \\
\text { Code }\end{array}$ & \multicolumn{1}{|c|}{ Participant Role } & Company \\
\hline 1A & Chief Executive Officer & Company A \\
\hline 2A & Fund Manager & Company A \\
\hline 3B & Non-executive Director & Company B \\
\hline 4C & Executive Management & Company C \\
\hline 5C & Executive Management & Company C \\
\hline 6C & Executive Management & Company C \\
\hline 7D & Regional Head & Company D \\
\hline 8E & Chief Executive Officer & Company E \\
\hline
\end{tabular}

\section{Company A}

Company A is an organisation that managers investors' funds. More specifically, they are fund managers that invest in listed property companies on the JSE. They do not operate in the same capacity as the other participating organisations that are purely REITs, and thus do not make decisions in the same manner as the other participating organisations. The purpose of selecting this organisation in the study is that they are experts in the REIT sector but also offer an objective opinion on the sector as they do not have a vested interest in a particular REIT portfolio or strategy.

\section{Company $B$}

Company B implemented the REIT structure in 2014 and has pursued exposure in the international market. The fund has a market capitalisation of R5.8 billion and holds a majority $(70 \%)$ of its stock in retail property. The 
other $30 \%$ is diversified amongst office and industrial property. Company B's portfolio has a Gross Lettable Area (GLA) of 520,226 $\mathrm{m}^{2}$.

Company $C$

Company $\mathrm{C}$ is the first, and only REIT listed on the JSE that specialises solely in residential property. It has a market capitalisation of R3.1 billion and its portfolio comprises of 7,000 residential units. Company $\mathrm{C}$ is one of a few specialised REITs operating out of South Africa.

\section{Company D}

With a market capitalisation of R82.8 billion, Company D is the biggest REIT in South Africa. The company features on the JSE top 40 index. The portfolio is made up of a combination of retail, office and industrial property with a total GLA of 6.73 million $\mathrm{m}^{2}$. While Company D does own residential stock, it represents such a small percentage of its portfolio that they do not disclose it in their report to shareholders.

\section{Company E}

Company E was listed on the JSE in 1998 and subsequently converted to a REIT structure. Their specialisation is in retail property, with a focus on nonmetropolitan nodes servicing low LSM brackets in the form of convenience, community and regional shopping centres, which are located close to transport nodes. Company E has a market capitalisation of R2.2 billion and owns 43 properties with a GLA of $229,175 \mathrm{~m}^{2}$.

Thematic analysis was the chosen method of analysis. This involves identifying the prominent themes that emerge from the data in order to link them back to the literature, which forms the analysis. The raw data (interview transcripts) were processed by using a qualitative software package, Nvivo. The software helped to establish a coding system that encapsulated common words or phrases, which resulted in deriving the central themes (Miles \& Huberman, 1994; Saldaña, 2015). Each respondent was analysed in isolation according to the themes that emerged from the data. A cross-respondent analysis followed this in order to conclude the similarities and differences between the respondents. This is discussed in the findings chapter.

\section{Findings and Data Analysis}

The findings have been presented thematically based on the analysis of data collected from the survey interviews. Findings have been categorised into three main themes which are presented below.

\subsection{Financial Performance of Residential Real Estate in South Africa}

The majority of research participants believed that residential real estate does not perform as well financially as other property classes. Correspondingly, 7D stated that most of the leading South African REITs portfolios comprise 
of office, retail and industrial property, and these three sectors dominate the investment property market. 1A highlighted that these property sectors have shown superior returns when compared to the residential sector and stated that the office sector could achieve yields of up to $12 \%$, while the residential sector would only achieve approximately $7 \%$. 1A went on to state that there are very few South African REITs that contain a residential portion.

1 A mentioned that the National Credit Act (NCA) hinders competitive returns in the residential sector. This is because the NCA prevents above inflationary increases for loan repayments for residential property. Since the loan repayment (income to the property owner) is capped, so too is the capital appreciation, as property values within an investment context are a function of income. 1A continues to state that if there is no capital appreciation, then this makes residential property a less attractive investment option, especially from an institutional investment perspective. Furthermore, as pointed out by $1 \mathrm{~A}$, rent control, residential lease structures and other benefits are offered to lessees in Europe, which results in increasing demand, thus making the residential sector an attractive investment option in foreign markets.

There have been times in the South African residential market when investors were getting excellent capital appreciation; however the income yield was still comparatively low. This, according to $1 \mathrm{~A}$ is one of the main reasons why there has been an aversion to residential stock in the listed property sector. This is confirmed by 3B who believes that returns in residential sector have been historically good; however the yields have not been competitive. $4 \mathrm{C}$ explains that although the residential sector is unable to achieve required returns, the sector is still outperforming the commercial sector. Moreover, 3B stated that in 2016 the total return (capital growth and income return) for some residential nodes in South Africa was 13.5\%.

While the respondents all agreed that the residential sector offers good capital returns, many felt that the income returns are not as favourable as other property classes. Additionally, 8E stated that because of the additional risks associated with residential property, funds would need to achieve yields of between $9 \%$ and $10 \%$ to compete with retail, industrial and office sectors. However, 3B highlighted that these returns could be achieved in the residential sector. He stated that the affordable housing ${ }^{1}$ sub-sector of the residential market is achieving yields of approximately $9-9.5 \%$, which is competitive with other main property classes. Furthermore, the participants from Company $\mathrm{C}$, a specialised residential REIT, stated that they were able to maintain their yield objectives. Thus, the findings suggest that the perception of the residential sector as being unable to compete with other sectors is, to some extent, inaccurate. This suggests that while this perception may influence the low uptake of residential stock in REITs, it is not the sole responsible factor.

\subsubsection{Offshore Investment}

\footnotetext{
${ }^{1}$ For the purposes of this paper affordable housing is characterised broadly by properties that are valued at less than R 1200000 (\$87500 USD based on exchange rate of R1= \$0.0729).
} 
A significant trend developing in the South African REIT sector is an increasing exposure to offshore investments. Out of the four listed companies that formed part of this study, all except Company C (the residential REIT) have international investments, most notably in Central and Eastern Europe. It is argued that this investment has been driven by low economic growth, the high cost of financing debt, and the weakened Rand in South Africa. Furthermore, 4C suggests that the South African property market is currently unstable. Essentially, these factors have stunted the further development of the domestic REIT sector. Invariably, this has meant that opportunities in the residential sector, and indeed other property sectors, are unexploited in favour of the attractive risk-reward profile available offshore. This is believed to also impact the uptake of residential stock in South African REITs. This brings up another important point, being that performance of various REITs is representative of the broader economy. Thus, for investment to be concentrated in the domestic market, the economy needs to be performing in a manner that offers opportunities for investment. The absence of which will lead investors to look for foreign alternatives.

\subsection{The Nature of Residential Real Estate in South Africa}

All of the respondents involved in this investigation agreed that the residential sector presents complex challenges regarding management intensity. 7D highlighted that these complexities act as barriers to the residential market. $1 \mathrm{~A}$ and $2 \mathrm{~A}$ similarly argue that management issues relating to both the nature of managing and maintaining residential property as well as rent leasing, renewals and terminations have meant that most investors do not have the appetite for residential real estate.

\subsubsection{Property Management Issues}

Most of the participants agreed that the management complexities of residential stock are a barrier to entering the residential market. 4C, 5C and 7D highlighted how the daily management issues are very different and are more personal, as you are managing someone's home. According to 8E, the management intensity in the residential sector is far more complicated than the commercial sector.

\subsubsection{Leasing, Renewals and Eviction}

All participants spoke extensively about the challenges with leasing and terminating residential property leases. $3 \mathrm{~B}$ stated that residential property is perceived to be riskier as vacancy rates tend to be relatively high, as result of short lease durations. 1A and 2A stated that in South Africa a residential lease is normally one year. Moreover, they noted that a major risk was the ability to get a secure tenant at a good escalation. This confirms the findings of a similar study where the inability to continuously escalate residential rentals was found to limit investment in this sector (Anderson \& Cloete, 2016). Therefore, ensuring that vacancy levels are kept at an acceptable standard while simultaneously maintaining other operational and financial needs provides a set of challenges that are unique to residential property. In addition 
to this, the sheer volume of leases that a REIT owning residential stock has to manage proves to be a laborious task.

Most participants commented on the number of leases involved in residential property. 4C stated that Company $\mathrm{C}$ owns 7,000 residential units, which means they have 7,000 leases in place, and month end reconciliations are an intensive procedure. Similarly, 8E also acknowledged that a residential portfolio would have more leases in place than a commercial portfolio. 7D suggested that with more leases comes an increase in costs of the management processes. As a result, 7D stated that higher volumes are required in order for residential property to become a financially viable option. This was alluded to in Anderson and Cloete's (2016) study which suggested that the scale required to list a residential REIT is limited by the availability of stock. Another aspect associated with leases was highlighted by 3B who explained that in a commercial lease the lessee is often a juristic person, while in most residential leases, the lessee is a natural person. This can create potential complications both managerially and socially.

Society recognises termination and eviction of lessees in a commercial environment as business as usual, however evicting a family from their home generally receives negative press. Respondents highlighted how this is a deterrent for listed property funds as they are public companies and thus their share price can be influenced by investor sentiment, which in turn is linked to society's perception of the company. Moreover, $8 \mathrm{E}$ states that the legal process of evicting a residential tenant is more prolonged compared to other property types. Eviction must be conducted in accordance with Prevention of Illegal Eviction (PIE) Act. 4C notes that this Act favours of the tenant however, this can act as a barrier from an asset management and potential acquisition perspective.

The above findings were also found in a similar study conducted by Anderson and Cloete (2016). However, it is argued that more developed markets in Europe and the US face the same, or similar, issues as mentioned above, yet their uptake of residential stock in REITs is much higher. While these issues may present additional concerns in South Africa in terms of the legislative environment, it is argued that they do not suffice to explain the vastly different weighting of residential stock in the listed sector when compared to other markets. The authors argue that there currently is not enough knowledge of these challenges and how to manage them. This is supported by $3 \mathrm{~B}$ who suggested that there is a lack of skills by practitioners that operate in the residential property sector in South Africa, and specialised residential expertise is required in order to extract attractive returns. Correspondingly, both $1 \mathrm{~A}$ and $2 \mathrm{~A}$ stated that it can be challenging to understand where and how the value in the residential sector is generated. The vast majority of participants admitted they do not have the required expertise to invest in residential property. This suggests that there is perhaps a lack of maturity in this aspect of the market. Most participants also recognised that the REITs sector in South Africa is far less mature than in developed markets such as Europe and the US. This will be discussed in detail in the next section. 


\subsubsection{Affordable Housing and Rentals in South Africa}

Housing affordability is a significant concern in South Africa. 3B stated that there was a lack of affordable residential stock in the range of R500,000 and $\mathrm{R} 1,200,000$. Addressing this deficit is a complex issue and developing affordable space in well-located nodes across the country is an increasingly difficult task for developers. The rising costs associated with developments have also encouraged developers to maximise their yields by providing highend residential units rather than affordable units. Some respondents commented on how REITs that invest in residential property are typically interested in high-end residential. Additionally, all respondents commented how there is a lack of supply of affordable housing in South Africa. However, $8 \mathrm{E}$ suggested that residential funds are beginning to target this bracket, in addition to the student housing market. Indeed, Company $\mathrm{C}$, the only REIT specialising in residential real estate, primarily let their properties to lower income earners and students (Muller, 2015). The respondents from this organisation also reported low vacancy rates, though they did not specify an amount.

Perceptions of renting versus owning were also brought up by a few participants. $8 \mathrm{E}$ compares the attitude towards renting in Europe to renting in South Africa. This is corroborated by $6 \mathrm{C}$ who noted there is more emotion to owning a house in South Africa compared to European markets. In Europe, it is considered socially acceptable for the middle class to rent property, while in South Africa most people strive to own property even if renting is the better financial option. Thus, those who can afford to rent high-end property would prefer to buy/build their own property.

Despite the above, it is argued that while affordability is a prevalent issue in South Africa, this issue is present globally, even in the most developed economies. This suggests that the affordability alone is not a dominant factor preventing the uptake of residential stock in South African listed funds.

\subsection{Maturity of the REIT Sector in South Africa}

All of the participants acknowledged that the REIT sector in South Africa is still in its infancy. A function of this immaturity is attributed to the diversified nature of listed funds, and minimal specialisation. Indeed, there is evidence that suggests that mixed-asset portfolios in emerging markets tend to perform better than that of developed markets (Georgia et al., 2007). 8E explains that the largest listed property funds on the JSE are general funds, with a combination of industrial, office and retail property. A typical South African REIT is diversified, and the concept of a specialised fund is relatively new. $1 \mathrm{~A}$ believes that there is a lack of specialised funds due to the relative infancy of the South African REIT market. However, the commercial, retail and industrial sectors of the South African REIT market appear to be reaching maturity (Anderson \& Cloete, 2016).

Despite this, funds in the listed sector have only managed to find meaningful institutional interest and scale to develop focused REITs as recently as 2015 . Thus, funds have applied a more risk-averse attitude towards specialisation 
and typically have not strayed from diversifying their portfolios. This is confirmed by $6 \mathrm{C}$ who explains that investors typically require a track record of three to five years to feel comfortable when making large capital investments. $4 \mathrm{C}$ supported this statement by saying that as specialised REITs gain traction in the South African market, so they will be considered by investors to be competitive with the diversified REITs. Therefore, as the REIT sector matures, it is likely that more specialised REITs (1A and 2A) will emerge. Several studies on REITs from more developed markets conclude that specialised REITs out-perform diversified REITs and that monetary gains made by diversified REITs are largely offset by increased costs (Boer et al., 2005; Brounen and de Koning, 2012; Chong et al., 2012). The issue, however, is that specialisation requires a concentration of skills and expertise, and the nature of residential real estate makes it hard to acquire these skills at the scale required for a REIT. This is because knowledge regarding residential real estate tends to be very localised (Turnbull \& Dombrow, 2007), and decisions made by potential buyers/tenants involves a multitude of complex factors.

Nevertheless, with this specialisation will come a greater uptake of residential stock in South African REITs (3B). 8E confirms this sentiment when stating that in the future the market may tend towards a more residentially focused REITs. This will require that residential yields build up a strong track record to prove to investors and property practitioners that the listed property sector can handle residentially focused funds.

However, to date, there has not been a record of success when listing a focused REITs and recorded listings were relatively unsuccessful (1A). Respondent $1 \mathrm{~A}$ goes on to mention that a residential property fund tried to list in the early 2000s. The listing was a failure at the time since the fund was too small, and the residential listing was too low. 3B felt that currently, the listed sector is too small to support many specialised REITs. There are currently four specialised REITs operating in the South African listed sector.

Despite the conflicting opinions, it was almost unanimously acknowledged that the sector will specialise and become more innovative like markets in the US and Europe, as the South African REITs market matures. Furthermore, participants called for greater specialisation in the sector. This corresponds with Anderson and Cloete's (2016) findings that highlighted that investors in the REITs sector would prefer to invest in residential stock through specialised residential REITs. This highlights the recognition of, and interest in, specialised and residential REITs.

\section{Discussion}

The findings section highlighted various key aspects that influence the uptake of residential stock in South African REITs. The majority of these issues are experienced in other parts of the world, notably in developed markets, where the portion of residential stock in the listed sector is significantly higher. It is likely that a combination of these factors have attributed to the low uptake of residential stock in South African REITs, however, these issues are 
exacerbated by the lack of requisite skills needed to make complex investment decisions relating to residential real estate. It is worthy to note that that many of the barriers cited by the interview respondents in this study were identified approximately twenty years ago in the UK (see Mansfield, 1999). According to Mansfield, UK property practitioners were apprehensive about compiling residential property portfolios due to a lack of data, high risk/low return profile, highly management intensive from both the physical asset and vacancy perspectives. The above suggests that the lack of maturity is a significant factor limiting the uptake of residential stock in South African REITs.

The perceived financial performance of residential property in South Africa, which is considered to be a key cause of the low uptake of residential stock, is inaccurate. Many participants highlighted that residential property could outperform other property sectors, which was supported by research conducted in Australia and the UK that revealed residential property could deliver high risk-adjusted returns and add value within a multi-sector portfolio (Montezuma, 2004; Lee, 2008). This suggests that the expertise regarding residential property investment, even amongst the upper management of listed funds, is lacking. The specialised nature of residential property means that investment can be risky if the right skills are not available to make investment decisions. This was pointed out by a couple of respondents. Ultimately, this lack of key expertise is related to the lack of maturity of the REITs sector in South Africa. It is argued that fostering this expertise will accelerate the development of the listed sector in South Africa. In turn, this is likely to lead to an increase in the uptake of residential stock in the listed sector.

Current under-development means that there is limited information on, and an unclear understanding of, the risks and opportunities exhibited by the residential property in the listed sector (Anderson \& Cloete, 2016). As a result, the dominant South African REITs do not invest in the residential sector. However, more specialised REITs are starting to gain traction. A similar study by Anderson and Cloete (2016) found that there was growing interest by REITs to invest in residential property, and that listed funds are starting to diversify their portfolios to include residential. However, they highlighted that a challenge to introducing more specialised residential REITs was the ability to generate the required scale of residential property to list on the JSE, which is perceived to be in excess of R 2 billion (Anderson \& Cloete, 2016).

Despite this, both studies indicate that residential stock is likely to become more prominent as asset managers acquire the necessary skills to extract the full value of this sector. Furthermore, most respondents stated their expectation; that with the development of these skills there will be a greater emergence of specialised residential REITs. Both the authors and respondents believe that this will primarily take place in the affordable housing bracket as this sector offers significant opportunities for investment, particularly in South Africa where there is a distinct lack of supply of affordable rental accommodation. This forecast is backed by a recent study where South 
Africa's affordable-housing market has exhibited attractive returns within the $8-10 \%$ range compared to the prime residential market of $5-5.5 \%$ (Suttner, 2018).

\section{Conclusion}

The South African listed property sector is diversified in nature, with a majority of the funds holding a combination of office, retail and industrial property. Despite the relative maturity of these asset classes in REITs, residential stock still lags far behind other asset classes on the listed sector. Moreover, the investment in residential stock is a new concept in South Africa, in comparison to other developed listed property markets. The purpose of this research was to determine what has influenced the low uptake of residential property within South African REITs. Thus, the research question is: Why is there relatively low uptake of residential stock within South African REITs?

This was answered through a qualitative survey comprising of semistructured interviews with key stakeholders involved in REITs and investing in the listed sector in South Africa. The study found that multiple reasons have attributed to the limited investment in residential property by REITs. These include the financial performance of residential real estate in South Africa; the nature of residential real estate in South Africa; and the maturity of South African REIT sector.

The most pertinent factor relating to the relatively low uptake of residential stock was identified as the maturity of the REITs sector in South Africa as this affects many of the other factors identified in this study. Furthermore, this has meant that there is a dearth of the requisite knowledge and understanding of residential real estate to facilitate greater uptake of this asset class. Thus, it is argued that fostering the skills and experience required to make informed investment decisions regarding residential property will help unlock the vast potential of residential real estate in South African REITs. Furthermore, it can help address issues associated with the housing backlog in South Africa by leveraging the resources of institutional investors and catalyse both domestic and international investment.

\section{References}

Anderson, L. Cloete, C.E. (2016). Potential for residential REITs in the South African REIT market. Presented at the 4th International Virtual Conference on Advanced Scientific Results, Slovakia, 6-10th June 2016.

Arizona State University. (2017). Real estate investment trusts (REITs) vs. real estate investing: Which fits your style? [Online]. Available: https://research.wpcarey.asu.edu/reits-vs-real-estate-investingwhich-fits-your-style/[Accessed 7 May, 2017].

Block, R.L. (2012). Investing in REITs: real estate investment trusts. Hoboken, N.J.: Bloomberg Press/Wiley. 
Bloomberg. (2016). July inflation rate falls to lowest in 2016 [Online]. Available: http://www.fin24.com/Economy/slight-drop-in-cpi20160824 [Accessed 15 May, 2017].

Boer, D., Brounen, D. and Optveld, H. (2005). Corporate Focus and Stock Performance International Evidence from Listed Property Markets. Journal of Real Estate, Finance and Economics, pp.263-281.

Broll. (2014). The Broll Report 2013/14. Sandton. Broll Property Group Pty Ltd. 2014

Brounen, D. and de Koning, S. (2012). 50 Years of Real Estate Investment Trusts: An International Examination of the Rise and Performance of REITs. Journal of Real Estate Literature, 20(2), pp.197-222.

Brounen, D. and de Koning, S. (2013). 50 years of real estate investment trusts: an international examination of the rise and performance of REITs. Journal of Real Estate Literature, 20(2), pp.197-223.

Centre for Affordable Housing Finance in Africa (CAHF).(2015). The South African Residential Property Market: An Overview [Online]. Available: http://housingfinanceafrica.org/app/uploads/The-SouthAfrican-Housing-Market-Overview-2015.pdf.

Centre for Affordable Housing Finance in Africa (CAHF).(2017a). Affordable Housing in Africa: A fact or a Fiction? In $4^{\text {th }}$ Affordable Housing in Africa Workshop [online]. Cape Town. Available at: https://housingfinanceafrica.org/app/uploads/olivier-vidalpresentation-Cape-town-July-2017-.pdf [Accessed: 20 ${ }^{\text {th }}$ June 2018].

Centre for Affordable Housing Finance in Africa (CAHF). (2017b). Real Estate Investment Trusts: What is the Potential for Residential REITs to Increase Investment in Affordable Housing in Africa? [Online]. Available: http://housingfinanceafrica.org/real-estateinvestment-trusts-potential-residential-reits-increase-investmentaffordable-housing-africa/. [Accessed: 20 ${ }^{\text {th }}$ June 2018].

Cheok, M. (2017) Singapore and Hong Kong Top World's Most Expensive Cities [Online]. Available: https://www.bloomberg.com/news/articles/2017-03-21/tokyoreturns-to-world-s-10-priciest-cities-in-asian-domination [Accessed 3 September, 2017].

Chong, J., Krystalogianni, A. and Stevenson, S. (2012). Dynamic correlations between REIT sub-sectors and the implications for diversification. Applied Financial Economics, Taylor \& Francis Journals, 22(13), pp.1089-1109.

Cliffe Dekker Hofmeyr. (2017). Reit legislation extended to unlisted property-owning companies [Online]. Available: https://www.cliffedekkerhofmeyr.com/en/news/publications/2015/ta $\mathrm{x} /$ budget-alert-2015-reit-legislation-extended-to-unlisted-propertyowning-companies-.html [Accessed 08 May 2017, 2017].

Coronation .(2017). UCT Portfolio Management [Online]. Available: https://vula.uct.ac.za/access/content/group/2284a3da-40e5-4820abdf-d4d78349e8a0/Guest Lecturers/UCT_AdG_Mar2017.pdf [Accessed 6 August, 2017].

De Klerk, E. (2013). Real Estate Investment Trusts ("REITs") legislation in South Africa. Presentation for SAREITs, Property Loan Stock Association, South Africa. 2-24. 
Delmendo, L. (2017). Japan's housing market remains buoyant [Online]. Available: https://www.globalpropertyguide.com/Asia/Japan/PriceHistory [Accessed 30 August, 2017].

DrWealth (2016) Singapore Real Estate Investment Trusts [Online]. Available: https://www.drwealth.com/reits/ - Residential [Accessed 3 September, 2017].

Dul, J. and Hak, T. (2007). Case Study Methodology in Business Research. Taylor \& Francis.

Euqub, S. (2017). Rental Yield Indicator [Online]. Available: http://www.interest.co.nz/saving/rental-yield-indicator [Accessed 30 August, 2017].

Georgia, C., Grissom, T. and Ziobrowski, A. (2007). The mixed asset portfolio for Asia-Pacific markets. Journal of Real Estate Portfolio Management, 13(3), pp.249-256.

Golding, A. (2016). South African property market predictions for 2017 [Online]. Available: https://www.privateproperty.co.za/advice/news/articles/southafrican-property-market-predictions-for-2017/5251 [Accessed 16 May, 2017].

Growthpoint. (2016). JCCI Presentation [Online]. Available: https://growthpoint.co.za/IRPresentations/JCCI Presentation - July 2016.pdf [Accessed 7 August, 2016].

Hamm, T. (2013). Is Moving Closer to Work Worth It? [Online]. Available: http://www.thesimpledollar.com/is-moving-closer-to-work-worth-it/ [Accessed 14 May, 2017].

Indluplace. (2017a). Profile. [Online]. Available: http://www.indluplace.co.za/1-profile.php [Accessed 19 May, 2017].

JSE-Limited (2010) Johannesburg Stock Exchange: Equity Market. [Online]. Available: https://www.jse.co.za/content/JSEBrochureItems/PropertyEntities.pd f [Accessed 14 ${ }^{\text {th }}$ August 2017].

Lee, C.L. (2008). Housing in Australia as a portfolio investment. International Journal of Housing Markets and Analysis, 1(4), pp.352-361.

Mansfield, J.R. (1999). Practical difficulties associated with constructing a residential investment portfolio. Property Management, 17 (4), pp.321-335.

Miles, M.B. and Huberman, A.M. (1994). Qualitative data analysis: An expanded sourcebook. SAGE Publications.

Miller, C. (2014). Analysis: REIT South African real estate investment trust structure introduced. Accountancy South Africa. [Online]. Available: https://www.accountancysa.org.za/analysis-reit-southafrican-real-estate-investment-trust-structure-introduced/

Montezuma, J. (2004). Housing investment in an institutional portfolio. Property Management, 22(3), pp.230-249.

J. Muller, Listed Property: New Listings Stack Up. From Financial Mail: [Online]. Available: http://www.financialmail.co.za/moneyinvesting/2015/07/02/listedpr operty-new-listings-stack-up [Accessed: 10th June 2018]. 
NAREIT. (2017a). Global Real Estate Investment [Online]. Available: https://www.reit.com/investing/reit-basics/global-real-estateinvestment [Accessed 20 March, 2017].

NAREIT. (2017b). US REIT Industry Equity Market Cap [Online]. Available: https://www.reit.com/data-research/data/us-reit-industryequity-market-cap [Accessed 2 August, 2017].

NAREIT. (2017c). What is a REIT? [Online]. Available: https://www.reit.com/investing/reit-basics/what-reit [Accessed 7 May, 2017].

Ntuli, M. and Akinsomi, O. (2017). An Overview of the Initial Performance of the South African REIT Market. Journal of Real Estate Literature, 25(2), pp.365-388.

Packer, F., Riddiugh, T. and Shek, J. (2014). A Global Tour of Commercial Property and REIT Markets [Online]. Available: http://www.umac.mo/fba/irer/papers/past/vol17n2_pdf/05.pdf [Accessed 1 August, 2017].

Patton, M. (1990). Qualitative evaluation and research methods [Online]. Available: http://legacy.oise.utoronto.ca/research/fieldcentres/ross/ctl1014/Patton1990.pdf [Accessed 22 August, 2017].

Property24.(2017). Johannesburg Property Trends and Statistics [Online]. Available: https://www.property24.com/johannesburg/propertytrends/100 [Accessed 15 May, 2017].

Ramjee, A. (2017). The determinants and predictability of South African listed property returns. Masters Dissertation. Department of Construction Economics and Management, The University of Cape Town. Available: https://open.uct.ac.za/bitstream/handle/11427/27393/thesis_ebe 201 7 ramjee anil.pdf? sequence $=1$

REIT Info .(2017).Canadian REITs [Online]. Available: http://reitinfo.com/index.php?option $=$ com_reitsearch\&q=\&sectionid $=3 \&$ catid $=45 \&$ subcategory $=$ [Accessed 8 August, 2017].

SA REIT. (2014). SA REIT Association Brochure [Online]. Available: http://www.sareit.com/docs/SA REIT brochure.pdf [Accessed 10 May, 2018].

SA REIT. (2017). SA REIT Association Property Journal, 2nd Edition, November 2017. Available: https://www.sareit.com/Journal/SAReit-Property-Journal-2.pdf

SA REIT. (2018). The Benefits of Investing in SA REIT [Online]. Available: http://www.sareit.com/101_Benefits.php [Accessed 20th February, 2018].

Saldaña, J. (2015). The coding manual for qualitative researchers. SAGE Publications.

Seftleben, G. (2016). Umhlanga property market boosted by influx of new business [Online]. Available: https://www.rawson.co.za/post/umhlanga-property-market-boostedby-influx-of-new-business [Accessed 16 May, 2017].

Sito, P. (2017). Hong Kong's reit market poised to gain from property slowdown in mainland China [Online]. Available: http://www.scmp.com/business/companies/article/1707545/hong- 
kongs-reit-market-poised-gain-property-slowdown-mainland [Accessed 7 September, 2017].

Smith, C. (2016). Western Cape property market stays on top [Online]. Available: http://www.fin24.com/Economy/western-cape-propertymarket-stays-on-top-20161118 [Accessed 15 May, 2017].

Suttner, K. (2018). Housing shortage: an opportunity for high investment yields [Online]. Available: https://www.ujuh.co.za/housingshortage-an-opportunity-for-high-investment-yields/[Accessed 17 May 2018].

The Economist.(2016). Global House Prices [Online]. Available: https://www.economist.com/blogs/graphicdetail/2017/03/dailychart-6 [Accessed 25 August, 2017].

The Guardian. (2015). London rises dramatically above New York in global prime property league [Online]. Available:

https://www.theguardian.com/money/2015/oct/06/london-outstripsnew-york-to-top-global-prime-property-league [Accessed 3 September, 2017].

Thistlethwayte, H. (2016). World Residential Markets [Online]. Available: http://pdf.euro.savills.co.uk/global-research/world-residentialmarkets-2015-2016.pdf [Accessed 7 August, 2017].

Turnbull, G.K. and Dombrow, J. (2007). Individual agents, firms, and the real estate brokerage process. The Journal of Real Estate Finance and Economics, 35(1), pp.57-76.

Withers, T. (2017). Housing Affordability Fires Up New Zealand's Voters [Online]. Available:

https://www.bloomberg.com/news/articles/2017-08-29/kiwisdefeated-by-crazy-house-prices-create-vote-battleground [Accessed 25 August, 2017].

World Bank. (2017). GDP Growth Rate [Online]. Available: https://www.google.com/publicdata/explore?ds=d5bncppjof8f9 \&m et $y=$ ny gdp mktp kd zg\&idim=country:ZAF:USA:AUS\&hl=en\& $\mathrm{dl}=\mathrm{en}$ [Accessed 15 May, 2017].

www.reits.co.za. (2017). Real Estate Investment Trusts South Africa [Online]. Available: http://www.reits.co.za/ [Accessed 14th April 2017, 2017].

Yin, R. (2006). The Case Study as a Research Method [Online]. Available: https://www.ischool.utexas.edu/ ssoy/usesusers/1391d1b.htm [Accessed 22 August, 2017].

Yin, R. (2013). Case Study Research: Design and Methods. SAGE Publications. 